\title{
The Ad Baculum Re-Clothed
}

\author{
ALAN BRINTON Boise State University
}

Key Words: Ad baculum; dialectical; force; logical form; sleaze factor; threat.

\begin{abstract}
In several recent articles, Michael Wreen has given a plausible account of the structure of ad baculum argument and argued that it is neither inherently fallacious nor even commonly so. He has also, arguing mainly in terms of examples, attempted to show that a number of common assumptions about the ad baculum are incorrect. Most controversially, he argues that the ad baculum is not essentially dialectical and that it does not essentially involve threatening. I argue that the genuineness of his examples as cases of ad baculum is doubtful, except insofar as they do at least implicitly have these features. I argue further that the stock cases used by Copi and other textbook writers extensionally define the ad baculum, which is a strategy already familiar to students from ordinary life, which is essentially first person/secondperson, and which does essentially involve a threat.
\end{abstract}

In one of his recent quartet of articles on ad baculum argument, Michael Wreen observes that, despite a flurry of recent activity by informal fallacy theorists, except for scanty textbook characterizations and a "scant, but not non-existent" body of professional literature, there is not much to report on the ad baculum. There is now, however, a good deal more to report, since Professor Wreen has singlehandedly provided us with his own little body of literature on the topic. ${ }^{1}$ The present essay is in part a report on and assessment of Wreen's contribution to our understanding of the ad baculum; but it is also an attempt to improve upon what he has given us to work with.

Let me begin by saying something about Professor Wreen's strategy. In the first place, he complains that standard textbook treatments of ad baculum argument (and of other so-called "informal falla- cies") "punk out" by grounding skimpy characterizations of the alleged fallacy in a few stock examples which are not subject-ed to serious analysis and by then advancing directly to exercises in which the student is asked to identify cases. Wreen's own method consists in much more detailed and methodologically self-conscious examination of a wider variety of examples, which he subjects to various reconstructions, with attention to context, standards of evidence, and relevant background information. He also bends over backward in an effort at charitable construal, always presuming arguments innocent until proven guilty, ever alert to possible grounds for logical acquittal. ${ }^{2} \mathrm{His}$ bending over backward in this way is, in my opinion, a useful corrective relative to standard textbook fallacy-identifications and judgments of guilty-without-trial.

Professor Wreen both sharpens and broadens the conception of ad baculum argument, grounding both the sharpening and broadening in his extensive examination of particular cases. The sharpening is straightforward and consists in his description of the logical structure of the ad baculum. Although very often expressed in a single statement, the typical case, fully spelled out, involves in Wreen's view an "if, then" premise, a second premise involving a negative evaluation of the "then" clause, and then as conclusion an "ought" or "ought not" statement about the "if" clause. A clear example, in standard form, would be the following:

If you don't give me your money, I'll shoot you in the head. Your being shot in the head would be a great evil you'd suffer- 
conspicuous line of argument appears to be grounded in examples. Let me focus attention on three sorts of cases described in "May the Force", which I will for convenience refer to as "extortion", "supermarket", and "simple warning" cases.

(1) Extortion Cases. Wreen and his diamond-ring-wearing companion are out for a stroll in one of these cases; the companion falls into quicksand and is allegedly adbaculized as follows (in canonical form):

If you don't give me your diamond ring, I won't help you get out and you'll die. Your dying is a great evil you would suffer. Therefore, you ought (from the point of view of self-interest) to throw me your diamond ring. ("May the Force," p.432)

(2) The Supermarket Case. "I'm not sure the local supermarket threatens me by demanding that I pay its prices or leave with no food...." says Wreen, "I, at least, would balk at describing the store as threatening me...." (p.432). He does not balk, however, (though one senses a slight hesitation) about describing the supermarket as engaged in adbaculism. In "A Bolt," he says "Grocery stores argue ad baculum, in effect, in (implicitly) saying 'If you don't pay this price..., you don't get this can of beans'" (pp.132-33).

(3) Simple Warning Cases. When Wreen yells out

\begin{abstract}
If you don't move from where you're standing, you'll get run over by a Mack truck and die. Your dying would be a great evil you would suffer. Therefore, you ought (from the point of view of self- interest) to move from where you're standing (p.433)
\end{abstract}

to his logical accomplice Walter Weber, "the argument's an ad baculum," though he is "just trying to save friend Weber" and is "certainly not threatening him...." Or if we suppose that Anytus, when he warns Socrates about speaking evil of people in Athens, really is warning rather than threatening, and possibly even hoping that Socrates will persist despite the danger, then again we have ad baculum without threatening. ${ }^{5}$

All these examples and their kin are, to be sure, possible cases. But of what? They leave us with two alternatives. Widening our conception of the ad baculum is one alternative. The other alternative is to reject the claim that they are examples of the $a d$ baculum. A real service is performed by bringing these cases to our attention. But maybe the appropriate response is to judge that these obviously are not ad baculums at all (though they look a lot like ad baculums once Professor Wreen puts them in canonical form) and then to try to clarify our understanding of the ad baculum by figuring out how they fall short of it. The mere presentation of these examples can carry very little weight in supporting the proposed expansion of the notion of ad baculum argument. All three are controversial. It almost seems too much even to say of mere warning cases that they are controversial; I think it fair to say that no informal logician who hasn't been temporarily charmed by Wreen is likely to think that warning a friend to jump out of the path of a truck is a case of ad baculum. The supermarket case will seem nearly as implausible to anyone who doesn't already have a bloated conception of the ad baculum. Extortion cases are arguable, especially if ingeniously formulated. But the requirements of ingenious formulation are in this instance a matter of making the extorting look enough like a threat so the "ad baculum" label has a chance of sticking.

As usual with Professor Wreen's strategic offenses, though, matters are not so simple. The main argument strategy which he overtly uses is to present us with his examples, which he simply introduces to us as ad baculums, and then to point out that they lack features usually associated with adbaculinity. Thus he hopes to free us from our prejudices. But again there is some theoretical grounding for these introductions. All of his examples instantiate what he has plausibly identified as the logical 
form of the ad baculum. They differ from stock cases only in terms of nonlogical features. Of course, so do entirely third-person inferences such as the following, made by a disinterested person observing Weber from a window several blocks away and speaking to himself

[A] If that fellow doesn't move from where he's standing, he'll get run over by a Mack truck. His getting run over by a Mack truck would be a great evil he would suffer. Therefore, he ought to move from where he's standing.

Not only will that be an ad baculum, but so will past tense cases such as

[B] If Caesar trusted Brutus, Caesar got assassinated. His getting assassinated was a great evil for him to suffer. Therefore, he shouldn't have trusted Brutus. ${ }^{6}$

It is not clear to me whether Professor Wreen would think that the second premise's involving an evaluation or the conclusion's involving an "ought" is a logical feature of the typical ad baculum. (I do know that he insists that the premises and conclusions be propositions, and that he rejects Charles Kielkopf's analysis of the ad baculum in terms of so-called "prescriptive meaning".7) But if not, then as a category in a logical scheme of classification the ad baculum is very wide indeed, apparently embracing a broad range of arguments which look sort of like modus tollens but which are non-deductive. How about the following case?

[C] If Mike buys that computer, he'll overspend his budget. Overspending his budget is not something Mike's inclined to do. Therefore, Mike's not likely to buy that computer.

Declaring [C] to be an example of the $a d$ baculum is the extreme to which we would appear to be driven by a serious insistence that the ad baculum is distinguished purely by its logical form. My impression is that Professor Wreen does not mean to go so far, but things seem to have gotten out of hand long before we get to [C]. I suggest that neither the supermarket case, nor simple warning cases, nor any of [A]-[C] ought to be thought of as ad baculums at all. One can define the sort of logical category Wreen has in mind, but it is not at all the class of inferences his predecessors had in mind when they coined the term "ad baculum", nor does it constitute a class of arguments which there is any good logical or nonlogical reason for providing with its own special name.

More closely akin to the ad baculum than any of the cases just rejected, so far as useful classification goes, are arguments of the following sort:

[D] If you take me to the prom, I'll buy you a diamond ring. Your getting a diamond ring would be a great benefit you would enjoy. Therefore, you ought to take me to the prom.

It will also not make very good sense to classify [D] as an ad baculum; but it is like an ad baculum on account of being firstperson/second-person and on account of involving something like a threat, namely a promise. But neither a promise nor a warning doth an ad baculum make. On what grounds though, if any, do I make these pronouncements? Well, on the grounds that what we had before the recent theorizing began was a sort of ostensive defining of the ad baculum in terms of stock examples. In our logical youth, we knew what Copi and his accomplices were talking about as soon as we saw their examples. We knew from bitter experience what it was to be adbaculized. Now we had a name for it. We didn't like having it done to us, though on occasion we might have done it ourselves, or enjoyed seeing it done, to others.

Instead of taking Professor Wreen's examples as supports for his account of the ad baculum, we might take them to be a sort of reductio ad absurdum of his approach. Obviously those aren't ad baculums; something must be wrong. If we 
assume (as I am willing to do) that his account of the logical features of the ad baculum is correct, then the reasonable conclusion is that an adequate characterization of the ad baculum will have to mention more than just its logical features. This will not mean that cases of ad baculum argument cannot be subjected to purely logical analysis and evaluation. It will just mean that what makes an ad baculum an ad baculum is more than just its logical features, and also that serious evaluation of ad baculums will require attention to whatever features distinguish them as a group from non-ad baculums of their same logical type.

There is a deeper issue here, which I have just been skirting. The trouble with ad baculums, I think Professor Wreen agrees, is more often moral than logical. The deeper problem with this type of argument is what may be appropriately called the sleaze factor. Now, Wreen rightly shrinks back from making sleaziness part of the definition of the ad baculum. But sleaziness is a real issue; and an adequate characterization of the ad baculum needs to identify defining characteristics of it which provide the grounding for adbacular sleaziness indictments. Adbacular sleaziness is grounded in the first-person/ second-person character of the ad baculum. That is to say, it is grounded in the fact that this kind of argument essentially involves an agent/patient relationship. The ad baculum involves one person's doing something to another person in a more specialized way than the way in which every arguer acts upon an arguee. Among the so-called "informal fallacies" (which I agree with Wreen in preferring to treat as kinds of arguments rather than as logical errors) are several which involve a more serious and more specialized agent/patient relationship than does your average argument. These more significant agent/patient relationships make the kinds of argument strategies which involve them problematic in some special ways; in particular, they make them liable to peculiar kinds of sleaziness. A problem with the use of stock examples in standard textbook treatments of the specially sleaziness-prone modes of argument is that they evoke feelings of disapprobation in the reader which are then attached to the mode of argument. When the treatment is part of an interlude in a program of logical analysis and evaluation, an undefined feeling that there is something wrong with the particular mode of argument translates into a kind of uneasy acceptance of the assumption that there must be something logically wrong. Thus arises the notion of "logical sleaziness."

Professor Wreen points out that there needn't be anything logically wrong with an ad baculum, and that it need not even have questionable premises. I hasten to add that there need not be anything morally wrong either. It would be an improvement if textbooks gave us some stock examples which don't go wrong in either way. If I say to my students "Look here, attendance has become a real problem in this class; I may have to start giving a few pop quizzes," that is clearly an ad baculum, one which is likely to be neither logically nor morally problematic. What really bugs us about offending ad baculums is that they are inappropriately coercive. The kind of agent/patient relationship they involve is a coercive one. The label "appeal to force" is perhaps infelicitous in that the ad baculum actually involves force in two senses, to the most important of which the label does less than full justice. On the one hand, in some of its instances it involves an appeal to force in the sense of threatening a use of force; in some cases, though not in all, it threatens some sort of "forceful" action against the recipient of the argument, as a possible consequence of failure to comply with the arguer's implicit or explicit request. If Professor Wreen threatens to beat me up unless I agree with him, he threatens to use force in that sense. On the other hand, the ad baculum involves force in another sense: it is itself a kind of 
forcing or coercion. What kind of coercion? Coercion by way of threats (sometimes threats of the application of force in the other sense). The name "appeal to force" emphasizes the inessential sense in which the ad baculum involves force and slights the essential sense: the ad baculum does not always threaten the application of forcible consequences; but it is always coercive. ${ }^{9}$

Successful use of the ad baculum presupposes a relationship of power; appropriate questions for its evaluation are typically questions about legitimacy in the exercise of power. The unjustly adbaculized person experiences a felt loss of autonomy and personal dignity. Such feelings, however, are not the test, since they may be incorrect or deserved.

Not only the role of the second person, or patient, is important, but also the role of the first person, or agent. A peculiarity of this mode of argument is that the arguer enters into the subject-matter of the argument, into the content, in a quasi-performative way. The arguer imposes his or her own presence, thereby creating within the argument itself a reason for action. A relevant question about this aspect of the matter is about the appropriateness of the kind of reason thereby created relative to the question at hand. Another is about the authority of the arguer.

According to my account, then, two of the most important facts about the ad baculum are that it is dialectical and that it involves threatening. It should be mentioned, however, that the second person need not be the person whose well-being is threatened, as Professor Wreen observes; but the second person must be the person addressed. Also, it should be observed that not every threat is an ad baculum. Consistently with Wreen's analysis, again, it is only threats which come at least implicitly in the "if, then" form (or an equivalent) which will fill the bill: "If you $\mathrm{Y}, \mathrm{I}$ 'll $\mathrm{X}$ you" will do; but a categorical "I'm going to $\mathrm{X}$ you" will not.

Finally, the view that the ad baculum involves the attempted exercise of power helps to explain why students sometimes confuse the ad baculum and the ad verecundiam. The ad baculum often involves the exercise and the threatened exercise of authority; and its legitimacy in particular cases is often a question of the legitimacy and the legitimate exercise of authority.

\section{Notes}

1 The articles are "Admit No Force But Argument," Informal Logic 10 (1988): 89-95; "A Bolt of Fear," Philosophy and Rhetoric 22 (1989): 131-140; "May the Force Be With You," Argumentation 2 (1988): 425-440; and "Yes, Virginia, There is a Santa Claus," Informal Logic 9 (1987): 31-39.

2 There is the suspicion, if one may be permitted the indulgence, that he is not beyond even getting an argument off on a technicality. He is, we might say, the William Kunstler of informal logic.

3 "May the Force," 430. I just note in passing that the argument could be as well represented as disjunctive, as ad baculums are often expressed in practice: "Your money or your life...", etc.
4 For an ingenious account of the theoretical underpinnings of this comment, see Michael Wreen, "When No Reason is Good Reason," Frans H. van Eemeren, et al, eds., Argumentation: Analysis and Practices: Proceedings of the Conference on Argumentation, 1986, vol. 3B (Dordrecht-Holland: Foris, 1987) 56- 64.

5 I should point out that Professor Wreen also thinks that neither waming nor threatening is required for the ad baculum. See "A Bolt," 139.

6 Wreen explicitly indicates that on his view ad baculum arguments can be third-person and concerning a "hypothetical or past state of affairs" ("A Bolt," p.134).

7 See "Admit No Force," 92. 
8 A little armchair psychology here, to be sure.

9 A referee points out, helpfully, that "argumentum ad baculum", unlike "appeal to force", contrasts with "argumentum ad rem". In its sometime reference to a threatened possible application of force (first sense) as a reason for action, the ad baculum is actually ad rem (as appears in Professor Wreen's analysis of its logical form). It is less than (or more than) ad rem, however, in being coercive. The same referee, to whom I am grateful for several other useful suggestions, makes the observation (which, I suspect, makes every informal fallacy theorist except Wreen tremble) that both textbooks and scholarly discussions of these matters ought to include more real-life examples. The referee suggests drawing the attention of readers to the following passage from the Port Royal Logic:

The very manner in which some religious tenets are urged on us determines their credibility. In different ages of the Church-principally in the last centurywe have seen men trying to spread their doctrines by sword and bloodshed; .... Any reasonable person will reject whatever is urged in so offensive a manner and not even the most stupid will listen. [Quoted by Hamblim, and said by him to be "the first appearanceunnamed - of the argumentum ad baculum". Fallacies (London: Methuen, 1970) pp. 156-157.]

The ad baculum refrerred to in the quotation is surely an interesting and important one; religious applications are of particular interest for a number of reasons. The reasoning of the passage itself, however, also involves a curious sort of "argument from anti-authority", whose form is something like this:

\section{$\mathrm{X}$ argues offensively ad baculum that $p$. Therefore, the doctrine that $p$ is incredi- ble and to be rejected by all reasonable persons.}

This form of argument will likely strike the reader as clearly fallacious; I will myself withhold judgment, however, until Professor Wreen has had a chance to mount its defense.

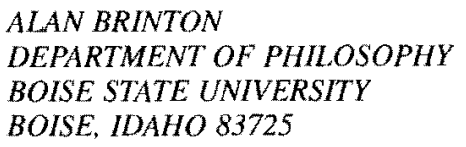

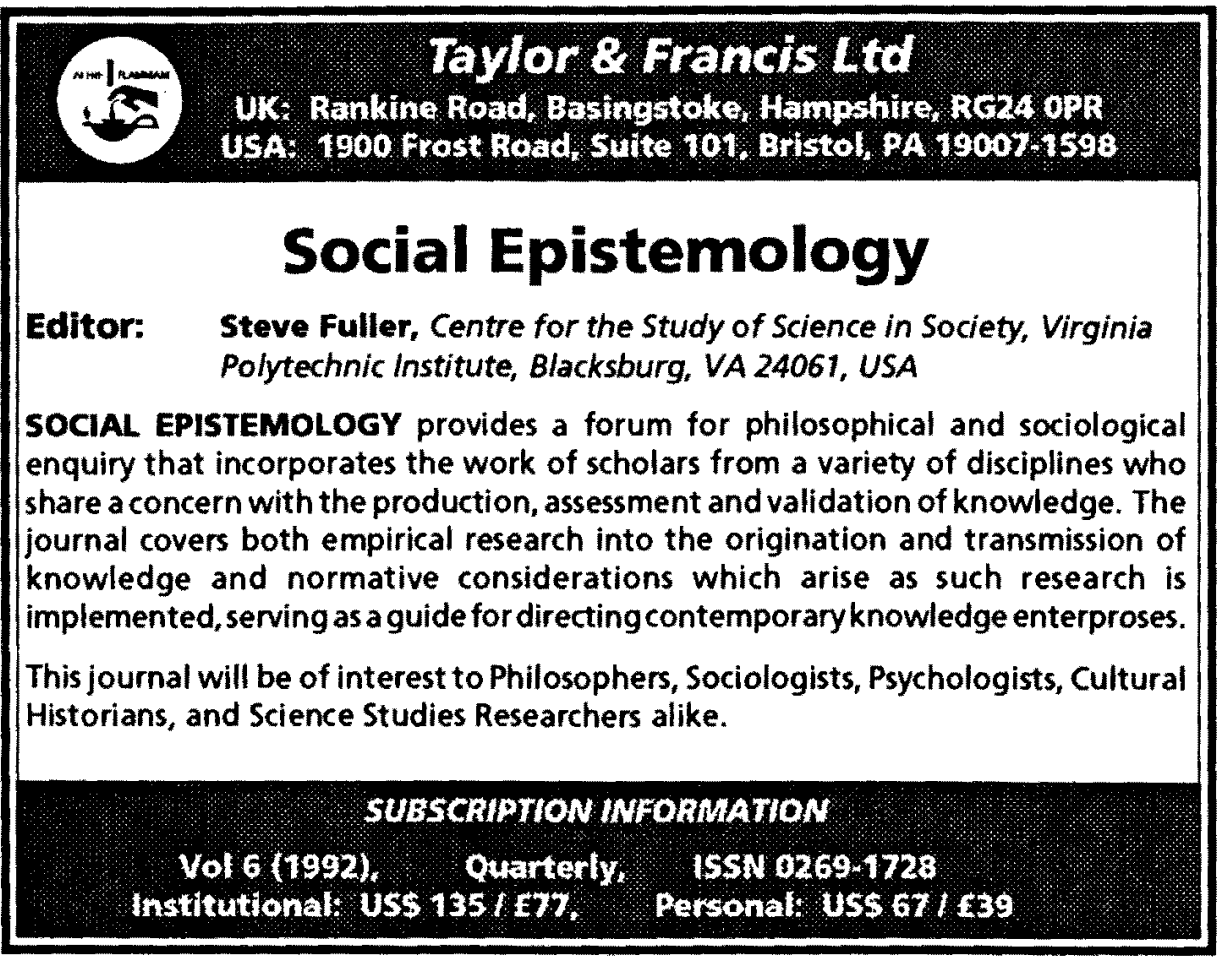

